Fixed Point Theory, 20(2019), No. 1, 591-600

DOI: $10.24193 /$ fpt-ro.2019.2.39

http://www.math.ubbcluj.ro/ ${ }^{\text {nodeacj/sfptcj.html }}$

\title{
STABILITY OF A CLASS OF FRACTIONAL INTEGRO-DIFFERENTIAL EQUATION
}

\author{
MUNIYAPPAN PALANIAPPAN* AND RAJAN SUBBARAYAN** \\ * Department of Mathematics, Adhiyamaan College of Engineering \\ Hosur, Tamil Nadu, India \\ E-mail: munips@gmail.com \\ ** Department of Mathematics, Erode Arts and Science College \\ Erode, Tamil Nadu, India \\ E-mail: srajan.eac@gmail.com
}

\begin{abstract}
The aim of the present paper is to investigate the Hyers-Ulam stability and generalized Hyers-Ulam stability of certain class of fractional integro-differential equation with boundary conditions using fixed point approach.

Key Words and Phrases: Hyers-Ulam stability, fractional integro-differential equation, boundary condition.
\end{abstract}

2010 Mathematics Subject Classification: 45J05, 47H10, 34K10.

\section{REFERENCES}

[1] M. Akkouchi, Hyers-Ulam-Rassias stability of nonlinear Volterra integral equations via a fixed point approach, Acta Univ. Apulensis Math. Inform., 26(2011), 257-266.

[2] L. Cădariu, V. Radu, Fixed points and the stability of Jensens functional equation, J. Ineq. Pure Appl. Math., 4(1)(2003).

[3] L.P. Castro, A. Ramos, Hyers-Ulam-Rassias stability for a class of nonlinear Volterra integral equations, Banach J. Math. Anal., 3(2009), 36-43.

[4] J.B. Diaz, B. Margolis, A fixed point theorem of the alternative, for contractions on a generalized complete metric space, Bull. Amer. Math. Soc., 74(1968), 305-309.

[5] M. Gachpazan, O. Baghani, Hyers-Ulam-Rassias stability of Volterra integral equations, J. Nonlinear Anal. Appl., 1(2010), 19-25.

[6] M. Gachpazan, O. Baghani, Hyers-Ulam-Rassias stability of nonlinear integral equations, Fixed Point Theory Appl., 2010 (2010), 6 pages.

[7] D.H. Hyers, on the stability of the linear functional equations, Proc. Nat. Acad. Sci., 27(1941), $222-224$.

[8] S.M. Jung, A fixed point approach to the stability of differential equations $y^{\prime}(t)=F(x, y)$, Bull. Malays. Math. Sci. Soc., 33(2010), 47-56.

[9] S.M. Jung, S. Sevgin, H. Sevli, On the perturbation of Volterra integro-differential equations, Appl. Math. Lett., 26(2013), 665-669.

[10] K. Karthikeyan, J.J. Trujillo, Existence and uniqueness results for fractional integro-differential equations with boundary value conditions, Commun. Nonlinear Sci. Numer. Simulat., 17(2012), 4037-4043. 
[11] C.P. Li, F.R. Zhang, A survey on the stability of fractional differential equations, Eur. Phys. J. Special Topics, 193(2011), 27-47.

[12] P. Muniyappan, S. Rajan, Hyers-Ulam-Rassias stability of fractional differential equations, Internat. J. Pure Appl. Math., 102(2015), 631-642.

[13] I. Podlubny, Fractional Differential Equations, Academic Press, London, 1999.

[14] Th.M. Rassias, On the stability of linear mappig in Banach spaces, Proc. Amer. Math. Soc., 72(1978), 297-300.

[15] S.M. Ulam, Problems in Modern Mathematics, Rend. Chap. VI, Wiley, New York, 1940.

[16] J. Wang, Linli Lv, Y. Zhou, New concepts and results in stability of fractional differential equations, Commun. Nonlinear Sci. Numer. Simulat., 17(2012), 2530-2538.

Received: September 9, 2016; Accepted: August 30, $201 \%$. 
